\title{
COMPULSORY LICENSING IN PHARMACEUTICAL INDUSTRY: CURRENT STATE OF AFFAIRS AND PROSPECTS
}

\author{
Gaydin $T Y^{1,2} \otimes$, Rozhnova $\mathrm{SA}^{1}$
}

${ }^{1}$ Pirogov Russian National Research Medical University, Moscow, Russia

${ }^{2}$ Lomonosov Moscow State University, Moscow, Russia

The problem of compulsory licensing $(\mathrm{CL})$ in the pharmaceutical industry is being discussed worldwide. The aim of this paper was to analyze the effects of using CL for pharmaceutical drugs (PD) as part of competitive policies aimed at safeguarding the life and health of the population. Using PEST-analysis, we identify the main political, economic, social and technological problems associated with using $\mathrm{CL}$ in the pharmaceutical industry. We demonstrate the potential of $\mathrm{CL}$ as a tool for countering the threats to public health caused by the abuse of market dominance by pharmaceutical patent holders. At present, both developers of pharmaceutical innovations (patent-holders) and other entities involved in drug circulation are protected by law. There is ongoing debate about the efficacy of $\mathrm{CL}$ as a tool ensuring the implementation of competitive policies aimed at safeguarding the rights to life and health. However, in Russia CL is applied only under exceptional circumstances. An economic balance should be sought between the incentives for innovation, long-term profits from selling PDs and PD accessibility.

Keywords: compulsory licensing, competition in pharmaceutical industry, drugs, PEST-analysis.

Author contribution: Gaydin TY analyzed the literature, conducted the study and wrote the draft of the manuscript; Rozhnova SA planned and conducted the study, analyzed the literature and wrote the draft of the manuscript

$\triangle$ Correspondence should be addressed: Timofey Gaidin

Ostrovityanova, 1, Moscow, 117997; gaty18a@econ.msu.ru

Received: 09.02.2021 Accepted: 22.02.2021 Published online: 09.03.2021

DOI: 10.24075/brsmu.2021.011

\section{ПРИНУДИТЕЛЬНОЕ ЛИЦЕНЗИРОВАНИЕ В ФАРМАЦИИ: ТЕКУЩЕЕ РЕГУЛИРОВАНИЕ И ПЕРСПЕКТИВЫ}

\author{
Т. Ю. Гайдин ${ }^{1,2} \otimes$, С. А. Рожнова ${ }^{1}$
}

${ }^{1}$ Российский научно-исследовательский медицинский университет имени Н. И. Пирогова, Москва, Россия

${ }^{2}$ Московский государственный университет имени М. В. Ломоносова, Москва, Россия

\begin{abstract}
Проблема применения принудительного лицензирования (ПЛ) актуальна для фармацевтических рынков во многих странах. Целью работы было проанализировать последствия применения ПЛ в системе обращения лекарственных средств (ЛС) для обеспечения охраны жизни и здоровья граждан в рамках конкурентной политики на рынке ЛС. С помощью PEST-анализа определены экономические, социальные, технологические и политические проблемы, связанные с ПЛ в фармации. Показаны возможности применения ПЛ как инструмента конкурентной политики для регулирования случаев злоупотреблений фармацевтическими компаниями-патентообладателями доминирующим положением на российском рынке ЛС, что приводит к снижению благосостояния потребителей и угрожает жизни и здоровью граждан. На сегодняшний день законодательством защищены как патентообладатели в сфере фармацевтической разработки, так и субьекты обращения ЛС. Продолжается дискуссия об эффективности возможного ПЛ как инструмента конкурентной политики для охраны жизни и здоровья граждан, но на сегодняшний день ПЛ в России применяют в исключительных случаях. Необходим поиск экономического баланса между стимулами к инновационной активности компаний, окупающих вложения в исследования и разработки, долгосрочным доходом с продажи ЛС и доступностью ЛС.
\end{abstract}

Ключевые слова: принудительное лицензирование, конкурентная политика в фармации, лекарственные средства, PEST-анализ

Вклад авторов: Т. Ю. Гайдин - работа с материалами, проведение исследования, подготовка черновика рукописи; С. А. Рожнова — планирование и проведение исследования, анализ литературы, подготовка черновика рукописи.

$\bigotimes$ Для корреспонденции: Тимофей Юрьевич Гайдин ул. Островитянова, д. 1, г. Москва, 117997; gaty18a@econ.msu.ru

Статья получена: 09.02.2021 Статья принята к печати: 22.02.2021 Опубликована онлайн: 09.03.2021

DOI: 10.24075/vrgmu.2021.011

Weak regulatory policies on compulsory licensing $(C L)$ are a setback to countering monopolies on the Russian pharmaceutical market. Recognizing CL as a legal tool for protecting the fundamental right to life and health might be a promising strategy. The world is faced with economic, political and social challenges that are escalating tensions in the pharmaceutical market and affecting the availability of pharmaceutical drugs (PDs). The mechanisms used to relieve these tensions at the national level include patent legislation and adequate drug supply to the population. At the international level, CL can be applied. In Russia, the Government has the right to authorize the use of a patented invention without the patent holder's consent in the interest of national defense and public safety. The patent holder must be promptly notified of the decision and is entitled to adequate remuneration [1]. The procedure is regulated by the Civil Code of the Russian Federation.
Innovative PDs are used to prevent, diagnose and manage diseases that could not be treated or cured in the past and to rehabilitate the affected patients [2]. Development of an innovative PD is a long, difficult, knowledge-intensive and costly process associated with a plethora of risks threatening to suspend or terminate the project [3]. A PD patent offers its proprietor the chance to recoup the costs of drug development, registration and marketing. Once a PD has been approved and registered, the patent holder has the right to decide on how and where the invention can be exploited. Due to the abuse of a dominant position by pharmaceutical companies, public access to some essential original drugs is limited.

Intellectual property law is the primary mechanism for recouping investments in drug development. Throughout the exclusivity period, a holder of a composition-of-matter, production technology or method-of-use patent remains the only 
Table 1. Examples of using CL in the pharmaceutical sector

\begin{tabular}{|c|c|c|c|c|c|}
\hline \multirow{2}{*}{$\begin{array}{l}\text { International nonproprietary name of a PD } \\
\text { or an active substance }\end{array}$} & \multicolumn{2}{|c|}{ Manufacturer } & \multirow{2}{*}{$\begin{array}{l}\text { PL issuing } \\
\text { country and year }\end{array}$} & \multirow{2}{*}{$\begin{array}{l}\text { Number of legal } \\
\text { proceedings }\end{array}$} & \multirow{2}{*}{ Grounds } \\
\hline & Original drug & Generic & & & \\
\hline Lenalidomide & $\begin{array}{l}\text { Celgene International } \\
\text { Holdings Corporation }\end{array}$ & Nativa, OOO & Russia, 2018 & 1 & Patent dependency \\
\hline $\begin{array}{l}\text { Lopinavir } \\
\text { Ritonavir }\end{array}$ & Abbot & $\begin{array}{l}\text { State-partnered } \\
\text { companies }\end{array}$ & Brazil, 2008 & 1 & \multirow{4}{*}{$\begin{array}{l}\text { Abuse of market } \\
\text { dominance }\end{array}$} \\
\hline Efavirenz & $\begin{array}{l}\text { Merck Sharp \& } \\
\text { Dohme }\end{array}$ & $\begin{array}{l}\text { State-partnered } \\
\text { companies }\end{array}$ & Brazil, 2007 & 1 & \\
\hline Sorafenib & Bayer & Natco Pharma Ltd. & India, 2012 & 1 & \\
\hline Lovastatin & Private company & $\begin{array}{l}\text { State-partnered } \\
\text { companies }\end{array}$ & $\begin{array}{l}\text { Canada, } \\
1980\end{array}$ & 1 & \\
\hline
\end{tabular}

representative of the patented product in the pharmaceutical marker. This allows the patent holder to address economic issues associated with product development.

However, patent law sometimes clashes with national security, the right to health, public welfare and technical progress. CL, which restricts the rights of a patent holder, is one of the mechanisms devised by the state to regulate such disagreements.

First and foremost, patent rights can be restricted in the best interest of national defense and security. The cases of conducting a research study, preparing a drug at a pharmacy for an individual patient, using a patented innovation in the event of emergency, etc. are not considered an infringement of the exclusive rights of a patent proprietor [1].

A compulsory license cannot be issued on account of overpricing, allowing pharmaceutical companies to abuse their dominant position in the market. Up to this day, there are no effective regulatory policies to protect against such abusive practices. A draft bill, which is currently under consideration in the State Duma, seeks to broaden the mandate of the Government so as to limit the rights of patent holders in the best interest of national defense and to uphold the rights to life and health [4].

In Russia, patent laws protecting the rights of a PD patent holder conform to international standards. So far, CL has not been used to resolve disagreements between pharmaceutical companies. However, in 2018 a compulsory license was issued by the court of law to allow a Russian-based pharmaceutical manufacturer Nativa to produce an analogue of a drug patented by the Celgene International Holdings Corporation; the situation sparked a lot of debate in the pharmaceutical sector [5].

\section{Aspects and prospects of $\mathrm{CL}$}

We collected and organized data on the use of $C L$ worldwide [6-10]; the results are presented in Table 1.

Table 1 illustrates that at the international level, legal grounds for issuing a compulsory license for a PD are limited to PD exclusiveness.

In Russia, the first compulsory license for a patented medicinal product was issued in 2018. Initially, the original drug was patented by Celgene International Holdings Corporation. A suit against Celgene was filed by the Russian company Nativa on grounds of patent dependency and following the refusal of the patent holder to license the drug to Nativa [5]. In other words, the compulsory license was issued because one patent was dependent on the other [6] but not because competition policy was being pursued to safeguard the life and health of the population. A significant reduction in the selling price was the main positive outcome of the court's decision [11].

Table 1 features cases of $\mathrm{CL}$ due to the abuse of market dominance by drug manufacturers [7-10]. In its current state, Russian legislation does not contain any provisions protecting against the abuse of a dominant position by a pharmaceutical company.

For this study, we compared wholesale prices for the original patented drug Revlimid (lenalidomide) and its generic using archived data from the State Registry of Maximum Wholesale Prices dated 08.06.2018 (Table 2).

\section{CL as factor for safeguarding the life and health}

To assess the feasibility of using $\mathrm{CL}$ as a tool for safeguarding the life and health of the population, we performed the PEST analysis of external political, economic, social, and technological factors that might influence the decision to issue a compulsory license for the generic drug Lenalidomide-Nativ. The factors were ranked by the force of impact in the descending order. For each factor, the force of impact was evaluated on a scale from 1 to 3 points, where 1 point represented mild impact, 2 points represented moderate impact and 3 points represented strong impact. For each external factor, the probability of change was estimated on a 5-point scale, where 1 point represented the minimal likelihood, and 5 points represented the maximum probability. Weight-corrected scores were obtained by multiplying the force of impact determined for the studied factor by the probability of change and dividing the resultant value by 34 , i.e. the total impact of the factor $[12,13]$.

Weight-corrected scores represent the real significance of the studied factors in determining the decision to issue the compulsory license for the drug and launch its domestic

Table 2. Comparison of maximum wholesale prices for the original drug lenalidomide and its generic (from https://grls.rosminzdrav.ru/)

\begin{tabular}{|c|c|c|c|c|}
\hline \multirow{2}{*}{$\begin{array}{c}\text { Dosage forms, strengths and } \\
\text { package sizes }\end{array}$} & \begin{tabular}{c} 
Maximum price, roubles \\
Manufactured by Celgene \\
\cline { 2 - 4 }
\end{tabular} & $\begin{array}{c}\text { Manufactured by Nativa } \\
\text { under trade name } \\
\text { Lenalidomide-Nativ } \\
\text { name Revlimid }\end{array}$ & $\begin{array}{c}\text { Difference in maximum } \\
\text { price }\end{array}$ & $\begin{array}{c}\text { Reduction in maximum } \\
\text { price, } \%\end{array}$ \\
\hline Seven 25 mg capsules & 453069.75 & 211584.80 & 241284.95 & 299213.00 \\
\hline Seven 10 mg capsules & 422000.00 & 122787.00 & 348899.00 \\
\hline Seven 5 mg capsules & 422000.00 & 73101.00 & $71 \%$ \\
\hline Seven 15 mg capsules & 443100.00 & 172389.00 & 270711.00 \\
\hline
\end{tabular}


Table 3. The analysis of external political, economic, social, and technological factors (PEST analysis) that might influence the decision to issue a compulsory license for the generic lenalidomide drug

\begin{tabular}{|c|c|c|c|c|}
\hline & Factor & Force of impact & Probability of change & Weight-corrected score \\
\hline \multicolumn{5}{|c|}{ Political factors } \\
\hline 1 & CL-related changes in the degree of intellectual property protection & 3 & 5 & 0.44 \\
\hline 2 & $\begin{array}{c}\text { Possible use of CL for safeguarding the life and health } \\
\text { of the population }\end{array}$ & 3 & 3 & 0.26 \\
\hline 3 & $\begin{array}{l}\text { Regulation of the pharmaceutical industry by the state: the registry of } \\
\text { essential drugs, which already includes lenalidomide-based drugs }\end{array}$ & 2 & 1 & 0.06 \\
\hline 4 & A new method for registering an essential drug price & 2 & 3 & 0.18 \\
\hline 5 & $\begin{array}{c}\text { Amendments to drug procurement legislation (priority is given to } \\
\text { Russian-based companies; local content policies) }\end{array}$ & 1 & 3 & 0.09 \\
\hline 6 & $\begin{array}{l}\text { Commitment of the state to a plethora of social policies articulated } \\
\text { in the Constitution and other statutory laws regulating drug } \\
\text { provision (drug procurement activities of the state have not } \\
\text { decreased substantially, as compared to the activities on the general } \\
\text { pharmaceutical market, in terms of value and considering the inflation rate) }\end{array}$ & 1 & 1 & 0.03 \\
\hline \multicolumn{5}{|c|}{ Social factors } \\
\hline 1 & The need for accessible lenalidomide & 3 & 2 & 0.18 \\
\hline 2 & The significance of a welfare state concept & 2 & 1 & 0.06 \\
\hline 3 & $\begin{array}{c}\text { Patients' awareness about the original drug and its generic affects the } \\
\text { demand (including the demand for lenalidomide) }\end{array}$ & 2 & 4 & 0.24 \\
\hline 4 & Demographics: population ageing & 1 & 1 & 0.03 \\
\hline 5 & $\begin{array}{c}\text { The need for better quality of life and improved performance in the } \\
\text { workplace in the face of increasing retirement age }\end{array}$ & 1 & 2 & 0.06 \\
\hline \multicolumn{5}{|c|}{ Economic factors } \\
\hline 1 & $\begin{array}{c}\text { Cutting state expenditures on PD procurement under targeted } \\
\text { programs for drug provision }\end{array}$ & 3 & 4 & 0.35 \\
\hline 2 & Falling incomes of the population & 2 & 3 & 0.18 \\
\hline 3 & $\begin{array}{l}\text { The impact of national currency dynamics on the price of PD or its } \\
\text { components }\end{array}$ & 2 & 2 & 0.12 \\
\hline \multicolumn{5}{|c|}{ Technological factors } \\
\hline 1 & $\begin{array}{l}\text { Insufficient investments in R\&D in the pharmaceutical industry } \\
\text { impeding the launch of innovative PD }\end{array}$ & 3 & 3 & 0.26 \\
\hline 2 & Insignificant export volumes (for both original PD and generics) & 2 & 4 & 0.24 \\
\hline 3 & $\begin{array}{l}\text { Limited access to state-of-the-art technologies for lenalomide-based } \\
\text { PD production }\end{array}$ & 1 & 3 & 0.09 \\
\hline Total: & 34 & 45 & & \\
\hline
\end{tabular}

Note: R\&D - research and development.

production. The higher the real significance of the factor shown in Table 3, the more effort is needed to reduce its negative impact. The results of the PEST-analysis are shown in Fig.

The analysis revealed that weakened intellectual property protection due to $\mathrm{CL}$ is the crucial political factor affecting the decision to launch the production of a generic; in our case this might drive the manufacturer of the original drug out of the Russian market. The registry of essential medicines is a mechanism of market regulation by the state: it allows the state to set a fixed price for a PD. Once a drug is excluded from the registry, the doors for competitive pricing will be opened because the manufacturer will no longer have to register the price for the product with the state. The most influential economic factor involves the cutting of state expenditures on drug procurement, which may give a competitive advantage to a generic. The most important social factor is patients' awareness about the original drug and its generic, because the negative opinion about the generic drug affects the demand.

Thus, CL for medicinal drugs aimed at protecting the life and health of the population may produce undesirable economic and other effects on the pharmaceutical market.

CL limits the rights of a patent-holder in cases when mass production of a drug is needed. In Russia, a compulsory license can be legally issued by the court of law following a third party's claim. The patent will be licensed to the third party if the court decides that there are sufficient grounds for $\mathrm{CL}$. The terms and conditions for $\mathrm{CL}$ are determined by the court.

In Russia, there are only 2 legal grounds for issuing a compulsory license. The first is the non-use of an innovation (a medicinal product in our case), a patented production prototype or a useful model over a certain time period. If the innovation is not produced in sufficient quantities to satisfy the market demand and the patent holder has refused to license the innovation to the third party that possesses the capacities to launch mass production of the innovation, the third party has the right to file a legal claim for the compulsory license. If the patent holder fails to prove that they were facing insurmountable obstacles preventing them from signing the agreement, the court is likely to issue a compulsory license to the third party.

The second legal ground for issuing a compulsory license is patent dependency. If an innovation cannot be manufactured without exploiting another patented innovation that bears no relation to the holder of the dependent patent, the latter has the right to seek a compulsory license for the original patent in court. The terms and conditions of patent transfer are specified by the original patent holder and determined by 


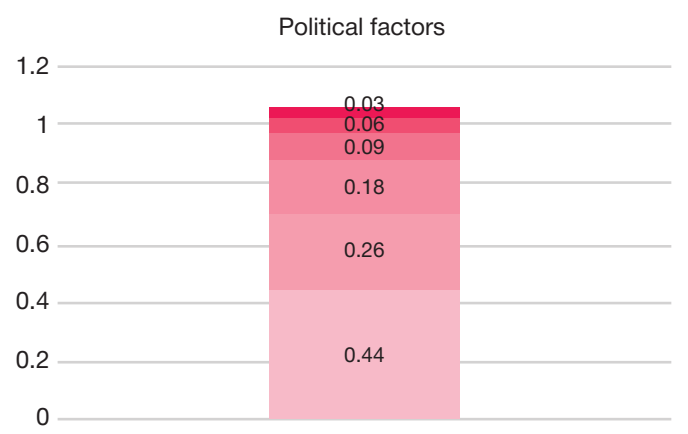

Commitment of the state to a plethora of social policies

State regulation of the pharmaceutical sector in the form of an essential drugs registry

Amendments to drug procurement legislation

A new method for registering an essential drug price

Using $C L$ as a factor of safeguarding the life and health of the population

Change in the strength of intellectual property protection

Social factors

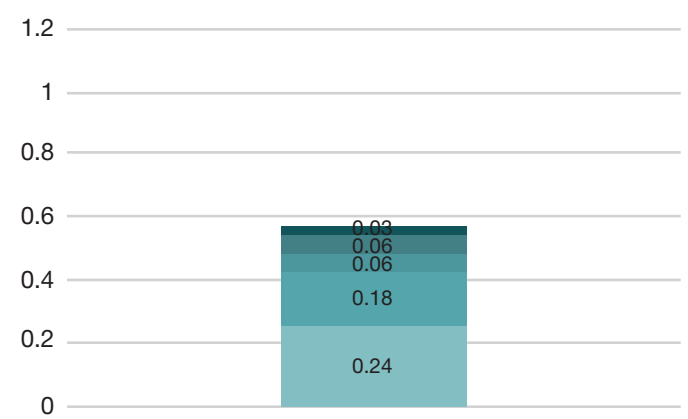

Demographics: population ageing

The need for better quality of life and improved performance in the workplace in the face of increasing retirement age

The significance of a welfare state concept

Patients need accessible PDs

Patients' awareness about the original drug and its generic affects the demand

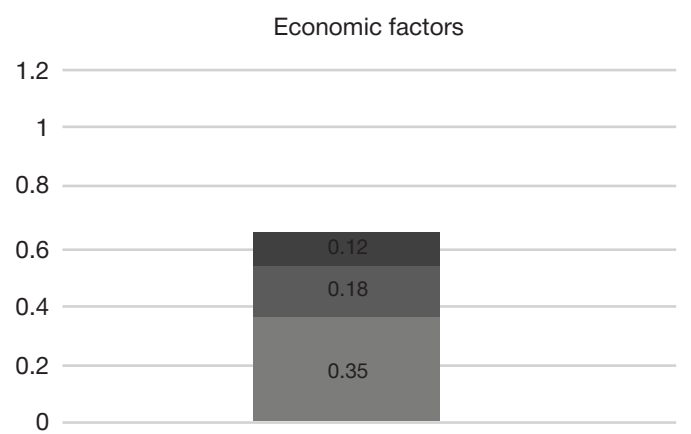

The impact of national currency dynamics on PD prices

Falling incomes of the population

Cutting state expenditures on PD procurement under targeted programs

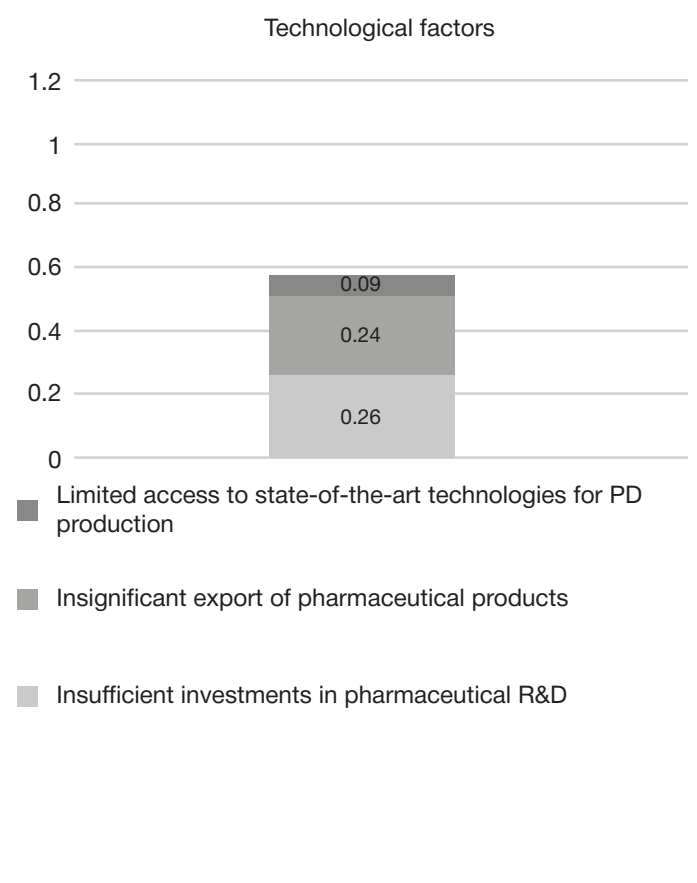

Fig. The results of the analysis of external political, economic, social and technological factors that impact the decision to launch production of lenalidomide-based generic drugs

the court. The obtained license cannot be transferred to other parties expect for cases of dependent patent transfer [1]. New regulatory mechanisms are being discussed to sort out such disagreements. A patent holder faces a number of additional risks of losing control over the invention. Similarly, the state faces a number of economic and non-economic problems (political, legislative, ethical) when trying to ensure that the demand for essential drugs is satisfied.

The price for an essential drug is established based on of the wholesale price, wholesale and retail markups [14]. Limits to wholesale and retail markups are set by the state. The wholesale price set by the manufacturer is the sum of production costs and profits. According to the Russian law on drug circulation, the maximum wholesale price set by a manufacturer for the drug included in the registry of essential medicinal products must be registered with the state. If the costs of production are low and the wholesale price is too high, public access to the drug will be limited. The state should seek to create a fair and economically justified balance of interests between the manufacturer and the consumer when fair competition and public wellbeing are at risk and the conflict of interests cannot be solved without state intervention. Damage to public welfare is not the sufficient reason for the manufacturer of the original drug (the monopolist) to lower the wholesale price; on the contrary, the manufacturer will raise the price, pointing to the substantial R\&D investments. The price might go down due to fair competition, but in order to produce a competitive generic, the rivaling company needs the manufacturing technology normally protected by the patent. So, in the event of market dominance abuse, CL might be viewed as a safeguard of the population's life and health. 
The relationship between competitive policies and innovation activities in different sectors of the economy is an attractive object of research [15-17]. Some authors describe CL as a mechanism for the implementation of competitive policies associated with the innovation activities of companies [16-18]. Some researchers [18-21] have proposed economic models suggesting that CL can significantly improve consumer welfare in some cases. Using an original model, researchers have demonstrated that CL effects on consumer welfare depend on the level of competition in the field; if the market is not competitive, CL will improve consumer welfare [18]. There are different ways of PD commercialization. Sometimes, intellectual property licensing can be applied: the right to launch mass production of the product is granted to another company on certain terms but the developer of the product retains the patent for the manufacturing technology. Often, the developer sells the manufacturing technology to another company. The most difficult and costly way is to launch independent production of the PD using the original manufacturing technology [22]. In such cases, CL should be applied with caution so as not to do irrevocable damage to the parties involved and not to violate the law.

The results of PEST analysis suggest that safeguarding the life and health of the population is the sufficient ground for issuing a compulsory license; it also improves public welfare in the short term.

There is a lot of controversy about using CL as a mechanism to regulate competition [23]. When viewed as a factor ensuring the right to life and health, CL is used as a component of competitive policies. It is reported that CL was effective in countering the abuse of a dominant position in the domestic market during the COVID-19 pandemic [24]; however, our findings suggest that the results of applying $C L$ might be controversial.

\section{Conclusion}

At present, the right to life and health cannot be appealed to as the legal ground to issue a compulsory license for medicinal products in Russia. Although CL poses significant risks for market competition, its regulatory potential can be estimated as powerful.

As a factor safeguarding the life and health of the population, CL can significantly improve consumer welfare as it makes essential drugs more accessible to consumers. CL will be instrumental in countering the abuse of market dominance by pharmaceutical companies.

\section{References}

1. Grazhdanskij kodeks Rossijskoj Federacii. 4 chast'. Available from: https://base.garant.ru/10164072/. Russian.

2. Romasanta A, van der Sijde P, van Muijlwijk-Koezen J. Innovation in pharmaceutical R\&D: mapping the research landscape. Scientometrics. 2020. 125 (3): 1801-32. DOI: 10.1007/s11192020-03707-y.

3. Rozhnova SA, Cypkina AV. Analiz sistemy organizacii farmacevticheskoj razrabotki lekarstvennyh sredstv. Razrabotka registracija lekarstvennyh sredstv. 2017; 3 (20): 170-178. Russian.

4. Zakonoproekt \# 842633-7 «O vnesenii izmenenija v stat'ju 1360 Grazhdanskogo kodeksa Rossijskoj Federacii». Available from: https://sozd.duma.gov.ru/bill/842633-7. Russian.

5. Reshenie ot 08.06.2018 Arbitrazhnogo suda goroda Moskvy po delu \# A40-71471/17-110-675. Available from: https://kad.arbitr. ru/Card/322413fa-38a7-4085-9cc7-3c8ff9fd7d92. Russian.

6. Postanovlenie Suda po intellektual'nym pravam ot 27.12.2018 \# S01-1064/2018 po delu \# A40-71471/2017. Russian.

7. Scopel C. Chaves G. Initiatives to challenge patent barriers and their relationship with the price of medicines procured by the Brazilian Unified National Health System. Cadernos de Saúde Pública. 2016. 32 (11): 1-11. DOI: 10.1590/0102-311X00113815.

8. Rodrigues W, Soler O. Licença compulsória do efavirenz no Brasil em 2007: contextualização. Revista Panamericana de Salud Pública. 2009; 26 (6): 553-559.

9. Burki T. Indian government awards compulsory licence for sorafenib. The Lancet Oncology. 2012; 13 (4): p.e146. DOl: 10.1016/S1470-2045(12)70108-0.

10. Steele JW. Generic Competition in Canada. PharmacoEconomics. 1994; 6 (5): 480-482. DOI:10.2165/00019053-199406050-00010.

11. Gosudarstvennyj reestr predel'nyh otpusknyh cen. Available from: http://grls.rosminzdrav.ru/PriceLims.aspx. Russian.

12. Mihailova OP. Metody marketingovoï diagnostiki vneshneï sredy promyshlennogo predprijatija $\vee$ konture strategicheskogo upravlenija. Bjulleten' Orenburgskogo nauchnogo centra UrO RAN. 2015; 3: 1-12. Russian.

13. Gailduk VI, Takaho YeE. Metody i instrumenty strategicheskogo planirovanija. Nauchnyï zhurnal KubGAU. 2014; 103 (09): 1-18.

\section{Russian.}

14. Federal'nyj zakon "Ob obrashhenii lekarstvennyh sredstv» ot 12.04.2010. Available from: http://www.consultant.ru/document/ cons_doc_LAW_99350/. Russian.

15. Shastitko AE, Kurdin AA. Stimuly k processnym innovacijam v diskretnyh strukturnyh al'ternativah konkurentnoj politiki. Voprosy jekonomiki. 2016; (4): 56-85. DOI: 10.32609/0042-8736-20164-56-85. Russian.

16. Goto A. Innovation and Competition Policy. JER. 2009; 60: 5562. DOI: 10.1111/j.1468-5876.2008.00466.x.

17. Federico G, Scott Morton F, Shapiro C. Antitrust and Innovation: Welcoming and Protecting Disruption. Innovation Policy and the Economy. 2020; 20: 125-190. DOl: 10.1086/705642.

18. Seifert J. Welfare effects of compulsory licensing. J Regul Econ. 2015; 48: 317-350. DOI: 10.1007/s11149-015-9288-9.

19. Bond E, Saggi K. Compulsory licensing, price controls, and access to patented foreign products. Journal Of Development Economics. 2014; 109: 217-228. DOI: 10.1016/j.jdeveco.2014.04.001.

20. Moser P, Voena A. Compulsory Licensing: Evidence from the Trading with the Enemy Act. American Economic Review. 2012; 102: 396-427. DOI: 10.1257/aer.102.1.396.

21. Sarmah A, De Giovanni D, De Giovanni P. Compulsory licenses in the pharmaceutical industry: Pricing and R\&D strategies. European Journal of Operational Research. 2020; 282 (3): 105369. DOI: 10.1016/j.ejor.2019.10.021

22. Gbadegeshin SA. The Effect of Digitalization on the Commercialization Process of High-Technology Companies in the Life Sciences Industry. Technology Innovation Management Review. 2019; 9 (1): 49-63. DOI: 10.22215/timreview/1211.

23. Acemoglu D, Akcigit U. Intellectual Property Rights Policy, Competition and Innovation. Journal of the European Economic Association. 2012; 10 (1): 1-42. DOI: 10.1111/j.15424774.2011.01053.x.

24. Abbott F, Reichman J. Facilitating Access to Cross-Border Supplies of Patented Pharmaceuticals: The Case of the COVID-19 Pandemic. Journal Of International Economic Law. 2020; 23 (3): 535-561. DOI: 10.1093/jiel/jgaa022. 


\section{Литература}

1. Гражданский кодекс Российской Федерации. 4 часть. Доступно по ссылке: https://base.garant.ru/10164072/.

2. Romasanta A, van der Sijde P, van Muijlwijk-Koezen J. Innovation in pharmaceutical R\&D: mapping the research landscape. Scientometrics. 2020. 125 (3): 1801-32. DOI: 10.1007/s11192020-03707-y.

3. Рожнова С. А., Цыпкина А. В. Анализ системы организации фармацевтической разработки лекарственных средств. Разработка и регистрация лекарственных средств. 2017; 3 (20): 170-178.

4. Законопроект № 842633-7 «О внесении изменения в статью 1360 Гражданского кодекса Российской Федерации» Доступно по ссылке: https://sozd.duma.gov.ru/bill/842633-7.

5. Решение от 08.06.2018 Арбитражного суда города Москвы по делу № A40-71471/17-110-675. Доступно по ссылке: https:// kad.arbitr.ru/Card/322413fa-38a7-4085-9cc7-3c8ff9fd7d92

6. Постановление Суда по интеллектуальным правам от 27.12.2018 № C01-1064/2018 по делу № A40-71471/2017.

7. Scopel C. Chaves G. Initiatives to challenge patent barriers and their relationship with the price of medicines procured by the Brazilian Unified National Health System. Cadernos de Saúde Pública. 2016. 32 (11): 1-11. DOI: 10.1590/0102311 X00113815.

8. Rodrigues W, Soler O. Licença compulsória do efavirenz no Brasil em 2007: contextualização. Revista Panamericana de Salud Pública. 2009; 26 (6): 553-559.

9. Burki T. Indian government awards compulsory licence for sorafenib. The Lancet Oncology. 2012; 13 (4): p.e146. DOI: 10.1016/S1470-2045(12)70108-0.

10. Steele JW. Generic Competition in Canada. PharmacoEconomics. 1994; 6 (5): 480-482. DOI:10.2165/00019053-199406050-00010.

11. Государственный реестр предельных отпускных цен. Доступно по ссылке: http://grls.rosminzdrav.ru/PriceLims.aspx.

12. Михайлова О. П. Методы маркетинговой диагностики внешней среды промышленного предприятия в контуре стратегического управления. Бюллетень Оренбургского научного центра УрО РАН. 2015; 3: 1-12.

13. Гайдук В. И., Такахо Э. Е. Методы и инструменть стратегического планирования. Научный журнал КубГАУ 2014; 103 (09): 1-18.

14. Федеральный закон "Об обращении лекарственных средств» от 12.04.2010. Доступно по ссылке: http://www. consultant.ru/document/cons_doc_LAW_99350/.

15. Шаститко А. Е., Курдин А. А. Стимулы к процессным инновациям в дискретных структурных альтернативах конкурентной политики. Вопросы экономики. 2016; (4): 5685. DOI: 10.32609/0042-8736-2016-4-56-85.

16. Goto A. Innovation and Competition Policy. JER. 2009; 60: 5562. DOI: 10.1111/j.1468-5876.2008.00466.x.

17. Federico G, Scott Morton F, Shapiro C. Antitrust and Innovation: Welcoming and Protecting Disruption. Innovation Policy and the Economy. 2020; 20: 125-190. DOI: 10.1086/705642.

18. Seifert J. Welfare effects of compulsory licensing. J Regul Econ. 2015; 48: 317-350. DOI: 10.1007/s11149-015-9288-9.

19. Bond E, Saggi K. Compulsory licensing, price controls, and access to patented foreign products. Journal Of Development Economics. 2014; 109: 217-228. DOI: 10.1016/j.jdeveco.2014.04.001.

20. Moser P, Voena A. Compulsory Licensing: Evidence from the Trading with the Enemy Act. American Economic Review. 2012; 102: 396-427. DOI: 10.1257/aer.102.1.396.

21. Sarmah A, De Giovanni D, De Giovanni P. Compulsory licenses in the pharmaceutical industry: Pricing and R\&D strategies. European Journal of Operational Research. 2020; 282 (3): 105369. DOI: 10.1016/j.ejor.2019.10.021.

22. Gbadegeshin SA. The Effect of Digitalization on the Commercialization Process of High-Technology Companies in the Life Sciences Industry. Technology Innovation Management Review. 2019; 9 (1): 49-63. DOl: 10.22215/timreview/1211.

23. Acemoglu D, Akcigit U. Intellectual Property Rights Policy, Competition and Innovation. Journal of the European Economic Association. 2012; 10 (1): 1-42. DOI: 10.1111/j.15424774.2011.01053.x.

24. Abbott F, Reichman J. Facilitating Access to Cross-Border Supplies of Patented Pharmaceuticals: The Case of the COVID-19 Pandemic. Journal Of International Economic Law. 2020; 23 (3): 535-561. DOI: 10.1093/jiel/jgaa022. 